\title{
INFLUÊNCIA DO GRAU DE TERRESTRIALIDADE NAS RESPOSTAS OSMORREGULATÓRIAS DE DUAS ESPÉCIES DE CARANGUEJOS SEMI-TERRESTRES MENIPPE NODIFRONS (STIMPSON, 1959) (BRACHYURA:MENIPPIDAE) E PACHYGRAPSUS TRANSVERSUS (GIBBES, 1850) (BRACHYURA:GRAPSIDAE)
}

\author{
Bozza, D.C. ${ }^{1,}{ }^{*}$; Freire, C.A. ${ }^{1}$ \& Prodocimo, V. $^{1}$ \\ ${ }^{1}$ Universidade Federal do Paraná (UFPR), Campus Centro Politécnico, Departamento de Fisiologia, Laboratório de \\ Fisiologia Comparativa da Osmorregulação. \\ *Autor correspondente: deivysonbozza@gmail.com
}

\begin{abstract}
A salinidade, assim como outros fatores abióticos, interfere diretamente na sobrevivência e distribuição das espécies. Os animais que vivem em ambientes entre-marés estão diariamente expostos às variações de salinidade e possuem adaptações fisiológicas para sobreviver nesses ambientes. As espécies de caranguejos semi-terrestres/ entre-marés Menippe nodifrons e Pachygrapsus transversus, embora pertençam a diferentes famílias, possuem uma distribuição semelhante pelo Atlântico Ocidental (América do Norte, Central e do Sul) e pelo Atlântico Oriental (África). Essas duas espécies vivem em ambientes semelhantes, na região entre-marés e em costões rochosos, sendo expostas diariamente a variação do ciclo de marés e ao ambiente terrestre. Porém, M. nodifrons é considerado mais aquático do que $P$. transversus, pois também é encontrado em poças de maré, em águas rasas e em bancos de ostras. O objetivo desse trabalho foi analisar os limites de tolerância e a osmorregulação de M.nodifrons e P.transversus, quando expostos por $6 \mathrm{~h}$ às salinidades de $0,10,20,30 \%$ (controle) e 40\%o $\mathrm{e}$ ao ambiente terrestre. Após a exposição às diferentes salinidades e ao ambiente terrestre foram mensurados a osmolalidade e os íons $\mathrm{Cl}^{-}$e $\mathrm{Mg}^{2+}$ da hemolinfa; o teor hídrico (TH) muscular e a atividade da enzima anidrase carbônica (AAC) nas brânquias posteriores (7 e 8). As duas espécies apresentaram 100\% de sobrevivência no ambiente terrestre e no ambiente aquático, em todas as salinidades, exceto em $0 \%$ onde a sobrevivência foi de $0 \%$ para as duas espécies. Esse estudo mostrou que as duas espécies possuem respostas osmorregulatórias parecidas, tanto no ambiente aquático quanto no ambiente terrestre. A osmolalidade aumentou ( 20\%) durante a exposição ao ambiente terrestre, em comparação ao controle, nas duas espécies estudadas, mostrando que a dessecação por um curto período de tempo pode contribuir com o aumento da concentração osmótica. OTH e a AAC mantiveram-se inalteradas, em comparação ao controle, nas duas espécies. $\mathrm{O} \mathrm{Cl}^{-}$de $M$. nodifrons diminuiu em $10 \%$ e $20 \%$ em comparação ao controle; e em P. transversus aumentou em $40 \%$ e no ambiente terrestre em comparação ao controle. As duas espécies mostraram ser bastante eurialinas e eficientes osmorreguladores, tanto em ambientes hipo-osmóticos quanto em ambientes hiper-osmóticos. Embora a espécie M. nodifrons seja mais aquática do que a espécie $P$. transversus, poucas foram as diferenças entre as duas espécies, diante dos desafios oferecidos.
\end{abstract}

Palavras-chave: osmorregulação, decapoda, salinidade, caranguejo. 